\title{
Effect of active dry yeast on lactation performance, methane production, and ruminal fermentation patterns in early-lactating Holstein cows
}

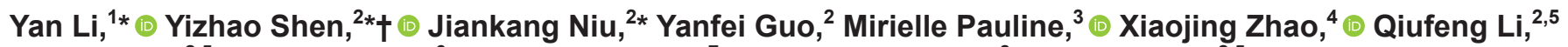 \\ Yufeng Cao, ${ }^{2,5}$ Chongliang $\mathrm{Bi}^{6}{ }^{6} \odot$ Xiujiang Zhang, ${ }^{7} \odot$ Zhonghua Wang, ${ }^{8} \odot$ Yanxia Gao, ${ }^{2,5} \dagger \oplus$ \\ and Jianguo $\mathrm{Li}^{2,5}+\odot$ \\ ${ }^{1}$ College of Veterinary Medicine, Hebei Agricultural University, Baoding 071001, Hebei, P.R. China \\ ${ }^{2}$ College of Animal Science and Technology, Hebei Agricultural University, Baoding 071001, Hebei, P.R. China \\ ${ }^{3}$ Department of Pediatrics, University of Alberta, Edmonton T6G 2R3, Alberta, Canada \\ ${ }^{4}$ Baoding Vocational and Technical College, Baoding 071000, Hebei, P.R. China \\ ${ }^{5}$ Hebei Cattle and Sheep Embryo Engineering Technology Research Center, Baoding 071001, Hebei, P.R. China \\ ${ }^{6}$ College of Agriculture and Forestry Science, Linyi University, Linyi 276005, Shandong, P.R. China \\ ${ }^{7}$ Baoding Husbandry Work Station, Baoding 071001, Hebei, P.R. China \\ ${ }^{8}$ Shandong Agricultural University, Taian 271000, Shandong, P.R. China
}

\begin{abstract}
This study was conducted to examine the effect of active dry yeast (ADY) supplementation on lactation performance, ruminal fermentation patterns, and $\mathrm{CH}_{4}$ emissions and to determine an optimal ADY dose. Sixty Holstein dairy cows in early lactation $(52 \pm 1.2 \mathrm{DIM})$ were used in a randomized complete design. Cows were blocked by parity $(2.1 \pm 0.2)$, milk production (35 \pm $4.6 \mathrm{~kg} / \mathrm{d})$, and body weight $(642 \pm 53 \mathrm{~kg})$ and assigned to 1 of 4 treatments. Cows were fed ADY at doses of 0, 10, 20, or $30 \mathrm{~g} / \mathrm{d}$ per head for $91 \mathrm{~d}$, with $84 \mathrm{~d}$ for adaptation and $7 \mathrm{~d}$ for sampling. Although dry matter intake was not affected by ADY supplementation, the yield of actual milk, $4 \%$ fat-corrected milk, milk fat yield, and feed efficiency increased quadratically with increasing ADY supplementation. Yields of milk protein and lactose increased linearly with increasing ADY doses, whereas milk urea nitrogen concentration and somatic cell count decreased quadratically. Ruminal $\mathrm{pH}$ and ammonia concentration were not affected by ADY supplementation, whereas ruminal concentration of total volatile fatty acid increased quadratically. Digestibility of dry matter, organic matter, neutral detergent fiber, acid detergent fiber, nonfiber carbohydrate, and crude protein increased quadratically with increasing ADY supplementation. Supplementation of ADY did not affect blood concentration of total protein, triglyceride, aspartate aminotransferase, and alanine aminotransferase, whereas blood urea nitrogen, cholesterol,
\end{abstract}

\footnotetext{
Received March 26, 2020.

Accepted August 7, 2020.

*These authors contributed equally to this work.

†Corresponding authors: yanxia.gao@hebau.edu.cn and 1181935094@qq.com
}

and nonesterified fatty acid concentrations decreased quadratically with increasing ADY supplementation. Methane production was not affected by ADY supplementation when expressed as grams per day or per kilogram of actual milk yield, dry matter intake, digested organic matter, and digested nonfiber carbohydrate, whereas a trend of linear and quadratic decrease of $\mathrm{CH}_{4}$ production was observed when expressed as grams per kilogram of fat-corrected milk and digested neutral detergent fiber. In conclusion, feeding ADY to earlylactating cows improved lactation performance by increasing nutrient digestibility. The optimal ADY dose should be $20 \mathrm{~g} / \mathrm{d}$ per head.

Key words: yeast product, nutrient digestibility, milk production, methane emission

\section{INTRODUCTION}

Active dry yeast (ADY) is a widely used feed additive in the dairy industry. It is reported to increase milk production and feed efficiency and decrease liver abscess (Desnoyers et al., 2009; Moallem et al., 2009; Crossland et al., 2019), which are also the benefits of the ionophore antibiotics monensin and tylosin (Van der Werf et al., 1998; Phipps et al., 2000). However, antimicrobial resistance increases with the supplementation of ionophore antibiotics (Shen et al., 2019a), which may potentially reduce the effectiveness of antimicrobial drugs for treating human disease. Thus, the use of ionophore antimicrobial has been banned by many countries, and ADY has been suggested as an alternative (Jia et al., 2018; Ran et al., 2018).

The positive effect of ADY on milk production and feed efficiency may be explained by the improvement of the ruminal environment. It is reported that ADY can scavenge ruminal oxygen, thereby providing a strict an- 
aerobic environment, which is beneficial for the growth of anaerobic bacteria (Fonty and Chaucheyras-Durand, 2006). Moreover, ADY is believed to stabilize ruminal $\mathrm{pH}$ by inhibiting production and increasing the utilization of ruminal lactic acid (Chaucheyras-Durand et al., 2005; Fonty and Chaucheyras-Durand, 2006). Because most cellulolytic bacteria can survive in an anaerobic environment with a $\mathrm{pH}$ above 5.8 (Russell and Wilson, 1996), greater NDF and OM digestibility with ADY supplementation should be expected (Desnoyers et al., 2009; Jiang et al., 2017a). Additionally, as reviewed by Chaucheyras-Durand et al. (2008), the ADY supplementation was suggested to potentially decrease $\mathrm{CH}_{4}$ emissions; however, the effect is inconsistent across studies (Lynch and Martin, 2002; Vyas et al., 2014; Muñoz et al., 2017),

Although the effect of ADY products on lactation performance and $\mathrm{CH}_{4}$ emission has been largely evaluated, the dose effect has been rarely evaluated. According to our previous survey (our unpublished data), more than $70 \%$ of the investigated farms in Baoding, China, use yeast products that exceed the recommended dose by $50 \%$. This led to the question, does a higher dose of ADY supplementation have additional benefits in early-lactating cows? The dose effect of ADY varies in different studies. Jiang et al. (2017a) carried out an experiment to evaluate ADY dose on production performance using dairy cows. A low dose of ADY supplementation increased milk yield significantly, whereas a high dose of ADY had no effect on milk production compared with control, demonstrating that more is not always better for ADY supplementation. However, Pinloche et al. (2013) found greater ruminal $\mathrm{pH}$ and lower ruminal lactic acid concentration when supplemented with a high dose of ADY, whereas no treatment effect was observed in the low ADY group. Ferraretto et al. (2012) also found that the NDF digestibility and milk fat percentage increased significantly with the supplementation of a high dose of ADY compared with a low dose. We hypothesize that a higher ADY dose would have additional benefits in dairy cows. Thus, the objective of this study was to examine the dose effect of ADY on lactation performance, ruminal fermentation patterns, and $\mathrm{CH}_{4}$ emission to determine an optimal ADY dose.

\section{MATERIALS AND METHODS}

This study was conducted between November 2017 and February 2018 at Hongda Dairy Farm in Baoding, China, and the experimental protocol (JGL 1712) was approved by the Institutional of Animal Care and Use Committee at Hebei Agricultural University (Baoding, China).

\section{Animals, Diet, and Experiment Design}

Sixty Holstein dairy cows (15 head/treatment) in early lactation $(52 \pm 1.2 \mathrm{DIM})$ were used in a randomized complete design. Cows were blocked by parity $(2.1 \pm$ $0.2)$, milk production $(35 \pm 4.6 \mathrm{~kg} / \mathrm{d})$ and body weight $(642 \pm 53 \mathrm{~kg})$ and assigned to 1 of 4 treatments. The treatments were a diet supplemented with 0 (control), 10,20 , or $30 \mathrm{~g}$ of ADY per day per head. The ADY in every diet was mixed with $72 \mathrm{~g}$ of ground corn and 18 $\mathrm{g}$ of molasses, split into 3 portions, and top-dressed 3 times daily at feeding. The ADY used was a strain of Saccharomyces cerevisiae purchased from Angel Yeast Co., Ltd. (Yichang, Hubei, China) with $2 \times 10^{9} \mathrm{cfu} / \mathrm{g}$. The recommended dose for lactating cows is $20 \mathrm{~g} / \mathrm{d}$ per head. The experimental period was $91 \mathrm{~d}$, with $84 \mathrm{~d}$ for adaptation and $7 \mathrm{~d}$ for sampling. The sample collection was conducted only in the final week of the experimental period to prevent negative effects on animal welfare and to achieve response consistency. This was an intensive sample collection with a large number of lactating cows (40 cows in total), and samples were collected from multiple sites (rumen, rectum, and blood). Such a collection schedule was necessary for the experiment objective but stressful for lactating dairy cows, which are sensitive to any human intervention and environmental changes. $\mathrm{CH}_{4}$ emissions, ruminal fermentation patterns, and blood indicators were measured before the experiment and did not differ among treatment groups; thus, these indicators were not used as covariates in statistical analysis.

Cows were housed individually in tiestalls with automatic drinking bowls. The diet contained $25 \%$ whole corn silage, $15 \%$ alfalfa hay, $2 \%$ oat hay, and $58 \%$ concentrate (DM basis; Table 1) and was formulated to meet the recommendation of NRC (2001). The cows were fed ad libitum (ensuring at least $5 \%$ refusals) at 0600, 1300, and $2000 \mathrm{~h}$, and they had free access to fresh water throughout the experiment. Cows were milked 3 times daily at 0500, 1200, and $1900 \mathrm{~h}$.

\section{Sampling and Data Collection}

Feed offered and refused for each cow was recorded daily during the experiment. The TMR, feed ingredients, and feed refusals were collected weekly, oven-dried at $55^{\circ} \mathrm{C}$ for $48 \mathrm{~h}$ to measure $\mathrm{DM}$ content, and then ground to pass through a 1-mm screen (stand model 4 Wiley Mill, Arthur H. Thomas, Philadelphia, PA) for chemical analyses. Daily DMI was calculated as the difference between DM offered and DM refusals. The DMI data were averaged weekly for statistical analysis.

Ten cows from each treatment were selected randomly for feces, blood, ruminal fluid, and $\mathrm{CH}_{4}$ sampling. Fecal 
samples (approximately $50 \mathrm{~g}$ wet) were collected from the rectum every $6 \mathrm{~h}$ from d 85 to 87 , pooled by cow, dried at $55^{\circ} \mathrm{C}$ for $48 \mathrm{~h}$, and ground through a $1-\mathrm{mm}$ screen (stand model 4 Wiley Mill; Arthur H. Thomas) for further analyses.

Blood samples were collected from the jugular vein on d 88 and 89. Before morning feed, approximately $40 \mathrm{~mL}$ of blood samples were collected into four 10-mL vacuum tubes (Vacutainer, Becton Dickinson, Franklin Lakes, NJ) containing $\mathrm{Na}$ heparin or no additive (2 tubes for each), and plasma and serum were prepared as described by Shen et al. (2019a). Plasma was used for the analysis of BUN, glucose, triglyceride, cholesterol, and NEFA, and serum was used for the analysis of total protein, aspartate aminotransferase (AST), and alanine aminotransferase (ALT). Both plasma and serum were stored at $-20^{\circ} \mathrm{C}$ until analyzed.

Ruminal samples (approximately $50 \mathrm{~mL}$ ) were collected using an oral stomach tube before the morning feeding on d 90 and 91 (Shen et al., 2012). Ruminal pH was measured immediately after collection using a portable pH meter (Starter 300, Ohaus Instruments Co. Ltd., Shanghai, China). After being squeezed through 4 layers of cheesecloth, 2 subsamples of $5 \mathrm{~mL}$ of ruminal fluid were mixed with $1 \mathrm{~mL}$ of $25 \%$ (wt/vol) $\mathrm{HPO}_{3}$ and $1 \mathrm{~mL}$ of $1 \%$ (wt/vol) $\mathrm{H}_{2} \mathrm{SO}_{4}$ and stored at $-20^{\circ} \mathrm{C}$ until the determination of VFA and ammonia. Milk production (actual milk yield), milk fat, and milk pro- tein concentration were recorded every day by cow and by milking time, using the Afikim milking system and averaged weekly for statistical analysis. Milk samples were collected 3 times daily from d 88 to 91 and stored at $-20^{\circ} \mathrm{C}$ until the analysis of lactose, MUN, and SCC.

Methane emissions were measured from d 85 to 88 , using the sulfur hexafluoride $\left(\mathbf{S F}_{6}\right)$ tracer gas technique as described by Chung et al. (2011). Briefly, a brass permeation tube $(10.5 \times 40 \mathrm{~mm})$ containing $1,836 \pm$ $56.6 \mathrm{mg}$ (mean $\pm \mathrm{SD}$ ) $\mathrm{SF}_{6}$ was used for $\mathrm{CH}_{4}$ collection. The release rates of $\mathrm{SF}_{6}$ were similar among treatments, ranging from 2.8 to $4.2 \mathrm{mg} / \mathrm{d}$ and averaging $3.45 \pm 0.41$ $\mathrm{mg} / \mathrm{d}$ (mean $\pm \mathrm{SD}$ ). Halters were placed on the animals before $0600 \mathrm{~h}$ on $\mathrm{d} 85$. The yoke canister was placed on the shelf above the cow at $0600 \mathrm{~h}$ on $\mathrm{d} 85$, connected to the halter, and replaced every $12 \mathrm{~h}$. The environmental concentration of $\mathrm{SF}_{6}$ and $\mathrm{CH}_{4}$ was monitored. The gas samples were collected from the yoke using syringes and analyzed immediately.

\section{Sample Analyses}

The content of DM, ash, ether extract, and CP (method 930.15, 942.05, 920.39 and 996.11, respectively; AOAC International, 2005) in TMR, feed refusal, and feces were determined according to AOAC International (2005). The OM content was calculated as $\mathrm{OM} \%=100 \%-\operatorname{ash} \%$. The content of NDF in

Table 1. Ingredients and chemical composition of the experimental diets

\begin{tabular}{|c|c|c|c|}
\hline Ingredient $^{1}$ & $\% \mathrm{DM}$ & $\begin{array}{l}\text { Chemical } \\
\text { composition }^{2}\end{array}$ & DM basis \\
\hline $\begin{array}{l}\text { Alfalfa hay } \\
\text { Oat hay } \\
\text { Whole corn silage } \\
\text { Cracked corn } \\
\text { Whole cotton seed } \\
\text { Steam-flaked corn } \\
\text { Wheat bran } \\
\text { Soybean meal } \\
\text { Dried beet pellet } \\
\text { Rapeseed meal } \\
\text { Corn DDGS } \\
\text { Premix } \\
\text { Extruded soybean } \\
\text { Molasses } \\
\text { Fat powder } \\
\text { Limestone } \\
\text { Calcium phosphate } \\
\text { MgO } \\
\text { NaHCO } \\
\text { NaCl } \\
\text { Mycotoxin adsorbent }\end{array}$ & $\begin{array}{r}15.00 \\
2.00 \\
25.00 \\
13.58 \\
5.93 \\
9.18 \\
1.39 \\
9.21 \\
5.38 \\
1.53 \\
1.65 \\
1.00 \\
4.10 \\
1.00 \\
2.26 \\
0.29 \\
0.56 \\
0.14 \\
0.59 \\
0.20 \\
0.01\end{array}$ & $\begin{array}{l}\mathrm{NE}_{\mathrm{L}}, \text { Mcal } / \mathrm{kg} \\
\mathrm{CP}, \% \\
\text { Ethanol extract, \% } \\
\text { NDF, \% } \\
\text { ADF, \% } \\
\text { Calcium, \% } \\
\text { Phosphorus, \% }\end{array}$ & $\begin{array}{r}1.64 \\
17.02 \\
5.13 \\
34.48 \\
20.44 \\
0.68 \\
0.37\end{array}$ \\
\hline
\end{tabular}


TMR, feed refusals, and feces was measured using heat stable $\alpha$-amylase and sodium sulfite (Van Soest et al., 1991). The ADF (method 973.18) contents in TMR, feed refusals, and feces were determined according to AOAC International (2005). Both NDF and ADF content were expressed including residual ash (Mertens, 2002). Acid detergent insoluble ash (ADIA) in TMR, feed refusals, and feces was used as an internal marker for apparent total-tract digestibility, and was determined as described by Van Keulen and Young (1977). Concentration of ruminal VFA was measured using gas chromatography (GC-14B, Shimadzu, Japan; $30 \mathrm{~m}$ $\times 0.32 \mathrm{~mm} \times 0.25 \mathrm{~mm}$; column temperature, $110^{\circ} \mathrm{C}$; injector temperature, $180^{\circ} \mathrm{C}$; and detector temperature, $180^{\circ} \mathrm{C}$ ) as described by Shen et al. (2019b).

Blood concentrations of BUN, total protein, glucose, triglyceride, cholesterol, NEFA, AST, and ALT were determined using commercial kits from Nanjing Jiancheng Bioengineering Institute (Nanjing, China). The interassay coefficients of variation were lower than $10 \%$, and the intra-assay coefficients of variation were lower than $12 \%$. Milk lactose was determined using a Milkoscan FT 120 (Foss Electric, Hillerød, Denmark), and SCC was determined using a Fossomatic cell counter (Foss Electric). The concentration of $\mathrm{SF}_{6}$ and $\mathrm{CH}_{4}$ were analyzed using a GC (GC-14B, Shimadzu, Kyoto, Japan; $1.8 \mathrm{~m} \times 0.3 \mathrm{~cm} \times 0.2 \mathrm{~cm}$; injector temperature, $180^{\circ} \mathrm{C}$; and detector temperature, $250^{\circ} \mathrm{C}$ ) according to Chung et al. (2011).

\section{Calculations and Statistical Analyses}

Apparent total-tract nutrients digestibility was estimated by using ADIA (Rice et al., 2019), and the equation was:

$$
100-(100 \times(\% \text { ADIA in DM consumed } /
$$

$\%$ ADIA in feces $) \times(\%$ nutrient in feces $/$

$\%$ nutrient in consumed DM)).

Data were analyzed using PROC MIXED procedure of SAS (SAS Institute Inc., Cary, NC) for a randomized complete design. Treatments were the fixed effects, and cows were the random effects. Sampling day was considered as a repeated measurement for variables measured over time. Week of feeding was considered as a repeated measurement for DMI and milk production. The repeated measures statistical analysis of results was subjected to 5 covariance structures: AR, UN, CS, $\mathrm{SP}$, and VC. The covariance structure that yielded the smallest Schwarz Bayesian criterion was chosen due to the most desirable and reliable analysis (Littell et al., 1998). The linear, quadratic, and cubic ADY dose responses were determined by using specific preplanned contrasts. Treatment effects were declared significant at $P \leq 0.05$, and trends were discussed at $0.05<P \leq$ 0.10 .

\section{RESULTS}

\section{Dry Matter Intake and Milk Production Characteristics}

Supplementation of ADY in the diet of Holstein cows in early lactation had no effect on DMI, whereas actual milk yield $(P=0.03), 4 \%$ FCM $(P=0.03)$, and feed efficiency ( $4 \%$ FCM/DMI; $P=0.05)$ increased quadratically with an increasing dose of ADY supplementation (Table 2). The percentage of milk protein and lactose did not differ among treatments, whereas a linear increase $(P<0.05)$ in milk fat and lactose yield and a trend $(P<0.10)$ with a linear increase in milk fat percentage and milk protein yield were observed with increasing ADY amount. The concentration of MUN followed a trend $(P=0.07)$ to quadratically decrease with increasing ADY supplementation. Compared with control, SCC decreased quadratically $(P=0.01)$ by $21.1,17.0$, and $7.1 \%$ in cows supplemented with 10,20 , and $30 \mathrm{~g}$ of ADY per day per head, respectively.

\section{Ruminal Fermentation Patterns and Nutrient Digestibility}

Ruminal $\mathrm{pH}$ was not affected by treatments (Table $3)$, whereas total VFA concentration increased quadratically $(P=0.04)$ with increasing ADY supplementation. Molar proportion of acetate tended $(P=0.08)$ to increase linearly, whereas molar proportion of butyrate tended $(P=0.06)$ to decrease linearly with increasing ADY supplementation. Molar proportion of propionate, ratio of acetate to propionate and ratio of acetate plus butyrate to propionate were not affected by treatments. Ruminal ammonia concentration was not affected by ADY supplementation. As showed in Table 4, the digestibility of nutrients including DM, OM, NDF, ADF, NFC, and CP increased quadratically $(P=0.01)$ with increasing ADY supplementation.

\section{Blood Metabolites}

Concentration of BUN decreased quadratically $(P=$ 0.05) with increasing ADY amount (Table 5), whereas no treatment effect was observed in total protein concentration. Blood concentration of glucose increased, whereas cholesterol decreased quadratically $(P=0.01)$ 
Table 2. Effect of active dry yeast (ADY) supplementation on DMI, milk production, and milk composition in lactating Holstein cows

\begin{tabular}{|c|c|c|c|c|c|c|c|c|}
\hline Item $^{1}$ & \multicolumn{4}{|c|}{ ADY supplementation, $\mathrm{g} / \mathrm{d}$ per head } & SEM & \multicolumn{3}{|c|}{$P$-value ${ }^{2}$} \\
\hline Actual & 34.7 & 35.6 & 36.2 & 35.7 & 0.25 & 0.02 & 0.03 & 0.49 \\
\hline $4 \% \mathrm{FCM}, \mathrm{kg} / \mathrm{d}$ & 31.8 & 33.0 & 34.6 & 34.2 & 0.37 & 0.01 & 0.03 & 0.15 \\
\hline \multicolumn{9}{|l|}{ Milk fat } \\
\hline \multicolumn{9}{|l|}{ Milk protein } \\
\hline$\%$ & 3.13 & 3.14 & 3.18 & 3.16 & 0.045 & 0.54 & 0.66 & 0.66 \\
\hline $\mathrm{kg} / \mathrm{d}$ & 1.09 & 1.12 & 1.15 & 1.13 & 0.018 & 0.06 & 0.12 & 0.19 \\
\hline \multicolumn{9}{|l|}{ Lactose } \\
\hline$\%$ & 4.76 & 4.71 & 4.72 & 4.78 & 0.028 & 0.67 & 0.04 & 0.97 \\
\hline $\mathrm{kg} / \mathrm{d}$ & 1.65 & 1.68 & 1.70 & 1.70 & 0.018 & 0.03 & 0.55 & 0.44 \\
\hline MUN, mg/dL & 13.8 & 13.6 & 13.2 & 13.8 & 0.21 & 0.74 & 0.07 & 0.31 \\
\hline
\end{tabular}

${ }^{1}$ Feed efficiency $=4 \%$ FCM $/$ DMI.

${ }^{2} \mathrm{~L}=$ linear, $\mathrm{Q}=$ quadratic, and $\mathrm{C}=$ cubic effects of ADY supplementation dose $(0,10,20,30 \mathrm{~g} / \mathrm{d}$ per head).

with increasing ADY supplementation, and a trend $(P$ $=0.09$ ) of a quadratic increase was also observed in triglyceride concentration. Blood concentration of AST and ALT was not affected by ADY supplementation, whereas NEFA concentration in cows supplemented 10,20 , and $30 \mathrm{~g}$ of ADY per day per head decreased quadratically $(P=0.01)$ by $9.32,10.17$, and $9.32 \%$ compared with control.

\section{Methane Production}

The results of $\mathrm{CH}_{4}$ production are shown in Table 6. Methane production was not affected by ADY supplementation when expressed as grams per day or per kilogram of actual milk yield, DMI, digested OM, and digested NFC. A trend of a linear and quadratic decrease respectively of $\mathrm{CH}_{4}$ production was observed when expressed as grams per kilogram of FCM $(P=$ $0.09)$ and digested NDF $(P=0.09)$.

\section{DISCUSSION}

As an active yeast product, ADY was reported to scavenge oxygen, increase redox potential, and reduce the accumulation of lactic acid to provide a better ruminal environment for ruminants (Chaucheyras-Durand and Fonty, 2002; Fonty and Chaucheyras-Durand, 2006; Chaucheyras-Durand et al., 2008). Moreover, in dairy cows, ADY was reported to increase DMI and nutrient digestibility, and thus be beneficial for milk production (Habeeb, 2017; Jiang et al., 2017a). In the present study, ADY was added in the diet of earlylactating dairy cows at the doses of $0,10,20$, and 30 $\mathrm{g} / \mathrm{d}$, to investigate the dose effect of ADY on lactation performance and $\mathrm{CH}_{4}$ emissions.

Though Habeeb (2017) reported an increase of DMI in dairy cows, the DMI was not affected by ADY supplementation in the present study, which was consistent with a previous study (Jiang et al., 2017a). The lack of

Table 3. Effect of active dry yeast (ADY) supplementation on ruminal fermentation patterns in lactating Holstein cows

\begin{tabular}{|c|c|c|c|c|c|c|c|c|}
\hline \multirow[b]{2}{*}{ Item } & \multicolumn{4}{|c|}{ ADY supplementation, $\mathrm{g} / \mathrm{d}$ per head } & \multirow[b]{2}{*}{ SEM } & \multicolumn{3}{|c|}{$P$-value ${ }^{1}$} \\
\hline & 0 & 10 & 20 & 30 & & $\mathrm{~L}$ & Q & $\mathrm{C}$ \\
\hline$\overline{\mathrm{pH}}$ & 6.36 & 6.27 & 6.22 & 6.25 & 0.294 & 0.56 & 0.67 & 0.93 \\
\hline Total VFA, $\mathrm{m} M$ & 75.4 & 77.5 & 85.4 & 75.8 & 2.35 & 0.42 & 0.04 & 0.06 \\
\hline Acetate (A), \% & 57.8 & 58.8 & 61.4 & 59.5 & 0.85 & 0.08 & 0.12 & 0.15 \\
\hline Propionate (P), \% & 23.2 & 24.0 & 23.8 & 24.2 & 1.03 & 0.55 & 0.85 & 0.69 \\
\hline Butyrate (B), \% & 13.7 & 11.1 & 9.8 & 10.3 & 1.21 & 0.06 & 0.23 & 0.92 \\
\hline $\mathrm{A} / \mathrm{P}$ & 2.50 & 2.48 & 2.59 & 2.46 & 0.132 & 1.00 & 0.68 & 0.55 \\
\hline$(\mathrm{A}+\mathrm{B}) / \mathrm{P}$ & 3.09 & 2.96 & 3.00 & 2.88 & 0.180 & 0.51 & 0.97 & 0.68 \\
\hline $\mathrm{NH}_{3}-\mathrm{N}, \mathrm{mg} / \mathrm{dL}$ & 13.6 & 12.9 & 10.9 & 12.0 & 1.26 & 0.28 & 0.49 & 0.66 \\
\hline
\end{tabular}

${ }^{1} \mathrm{~L}=$ linear, $\mathrm{Q}=$ quadratic, and $\mathrm{C}=$ cubic effects of $\mathrm{ADY}$ supplementation dose $(0,10,20,30 \mathrm{~g} / \mathrm{d}$ per head). 
Table 4. Effect of active dry yeast (ADY) supplementation on nutrient digestibility in lactating Holstein cows

\begin{tabular}{|c|c|c|c|c|c|c|c|c|}
\hline \multirow[b]{2}{*}{ Item $^{1}$} & \multicolumn{4}{|c|}{$\begin{array}{l}\text { ADY supplementation, } \\
\text { g/d per head }\end{array}$} & \multirow[b]{2}{*}{ SEM } & \multicolumn{3}{|c|}{$P$-value ${ }^{2}$} \\
\hline & 0 & 10 & 20 & 30 & & $\mathrm{~L}$ & $\mathrm{Q}$ & $\mathrm{C}$ \\
\hline OM, $\%$ & 68.8 & 73.8 & 73.2 & 71.2 & 1.16 & 0.24 & 0.01 & 0.43 \\
\hline DM, \% & 67.0 & 72.9 & 72.4 & 69.4 & 1.28 & 0.27 & 0.01 & 0.50 \\
\hline NDF, $\%$ & 57.7 & 62.3 & 62.9 & 59.0 & 1.40 & 0.35 & 0.01 & 0.90 \\
\hline $\mathrm{ADF}, \%$ & 53.0 & 60.0 & 60.0 & 56.1 & 1.90 & 0.29 & 0.01 & 0.73 \\
\hline NFC, $\%$ & 85.0 & 89.5 & 88.7 & 87.0 & 0.76 & 0.16 & 0.01 & 0.21 \\
\hline $\mathrm{CP}, \%$ & 71.4 & 76.4 & 76.6 & 73.4 & 1.03 & 0.21 & 0.01 & 0.78 \\
\hline
\end{tabular}

ADY effect on DMI was reported in both dairy cows (Malekkhahi et al., 2016) and beef cattle (Vyas et al., 2014) previously, using similar yeast products (Saccharomyces cerevisiae). As reported by Chaucheyras-Durand et al. (2012), the ADY supplementation is more relevant during challenges, such as a feed transition or periods of stress. In the present study, the diet was unchanged and the cows were not suffering from any stress; thus, the lack of ADY effect on DMI, which was consistent with previous studies, should be expected.

In the present study, the increased actual milk yield and 4\% FCM yield in ADY-supplemented cows were consistent with previous studies (Desnoyers et al., 2009; Moallem et al., 2009; Jiang et al., 2017a). However, no treatment effect on milk yield was reported previously (Ferraretto et al., 2012; DeVries and Chevaux, 2014). The varied results among studies could be explained by the different ADY strains used. Furthermore, Chaucheyras-Durand et al. (2008) believed that ADY supplementation could be more relevant in a high concentrate diet; the effect of ADY supplementation on milk yield could also be affected by the concentrate content in different diets. The positive effect of ADY on FCM yield reported by Moallem et al. (2009) and Jiang et al. (2017a) used a high concentrate (68 and 58.3\%, respectively) diet, whereas Ferraretto et al. (2012) and DeVries and Chevaux (2014), who did not find an ADY effect on FCM yield, used a low concentrate ( 32.7 and $42.3 \%$, respectively) diet. The diet used in the present study is a high concentrate diet (58\% concentrate); thus, the greater milk production in ADYsupplemented cows is expected. Jiang et al. (2017a) found greater milk yield when they supplemented with a low dose of ADY but not with a high dose, suggesting that higher levels of ADY supplementation may not be better. In the present study, the quadratically increased milk yield and FCM yield in ADY-supplemented cows illustrated that the supplementation of ADY at $20 \mathrm{~g} / \mathrm{d}$ per head should be enough for increasing milk yield.

Milk fat production is greatly affected by ruminal acetate production in dairy cows, because acetate is an important precursor of milk fat (Popjak et al., 1951). In the present study, the linearly increased milk fat content and yield were consistent with the linearly increased acetate molar proportion. Similar increased milk fat with ADY supplementation was also reported previously (Ferraretto et al., 2012; Jiang et al., 2017a).

The concentration of MUN is usually used to represent nitrogen balance; less MUN suggested a better utilization of nitrogen in the mammary gland. The decreased MUN was also reported by Dehghan-Banadaky et al. (2013). They believe that the decreased MUN

Table 5. Effect of active dry yeast (ADY) supplementation on blood metabolites in lactating Holstein cows

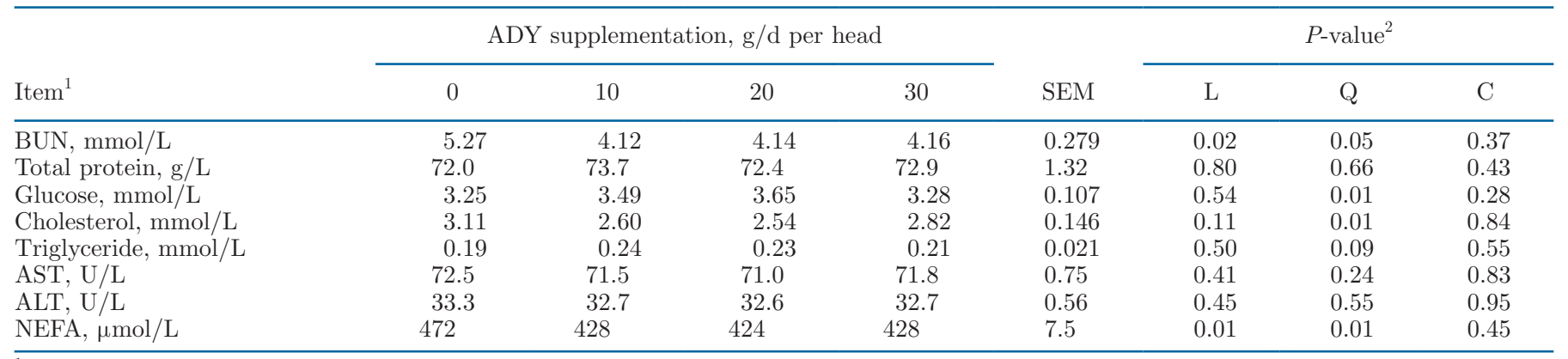

${ }^{1} \mathrm{AST}=$ aspartate aminotransferase ALT $=$ alanine aminotransferase; NEFA = nonesterified fatty acid.

${ }^{2} \mathrm{~L}=$ linear, $\mathrm{Q}=$ quadratic, and $\mathrm{C}=$ cubic effects of ADY supplementation dose $(0,10,20,30 \mathrm{~g} / \mathrm{d}$ per head). 
Table 6. Effect of active dry yeast (ADY) supplementation on methane emission in lactating Holstein cows

\begin{tabular}{|c|c|c|c|c|c|c|c|c|}
\hline Item $^{1}$ & \multicolumn{4}{|c|}{ ADY supplementation, g/d per head } & SEM & \multicolumn{3}{|c|}{$P$-value ${ }^{2}$} \\
\hline $\mathrm{CH}_{4}, \mathrm{~g} / \mathrm{d}$ & 344 & 349 & 340 & 344 & 11.6 & 0.83 & 0.97 & 0.66 \\
\hline $\mathrm{CH}_{4} / \mathrm{FCM}, \mathrm{g} / \mathrm{kg}$ & 10.7 & 10.6 & 10.1 & 9.9 & 0.38 & 0.09 & 0.96 & 0.56 \\
\hline $\mathrm{CH}_{4} / \mathrm{DMI}, \mathrm{g} / \mathrm{kg}$ & 15.3 & 15.4 & 15.0 & 15.0 & 0.51 & 0.59 & 0.93 & 0.66 \\
\hline $\mathrm{CH}_{4} / \mathrm{OMD}, \mathrm{g} / \mathrm{kg}$ & 21.7 & 21.2 & 20.4 & 20.4 & 0.79 & 0.18 & 0.72 & 0.75 \\
\hline
\end{tabular}

${ }^{1} \mathrm{MY}=$ milk yield; OMD $=$ digested $\mathrm{OM} ; \mathrm{NDFD}=$ digested NDF; NFCD = digested NFC.

${ }^{2} \mathrm{~L}=$ linear, $\mathrm{Q}=$ quadratic, and $\mathrm{C}=$ cubic effects of $\mathrm{ADY}$ supplementation dose $(0,10,20,30 \mathrm{~g} / \mathrm{d}$ per head).

should be explained by the greater microbial activity and greater incorporation of $\mathrm{NH}_{3}$ into microbial protein in the rumen. In the present study, although the ruminal ammonia concentration was not affected, the greater NDF and ADF digestibility may approve this hypothesis. Somatic cell count is an important indicator to evaluate the inflammatory response in ruminants. Although the SCC was not affected in some studies (Moallem et al., 2009; De Ondarza et al., 2010), the decreased SCC in cows supplemented with ADY were reported by Degirmencioglu et al. (2013) and Szucs et al. (2013), which were consistent with the present study. Bobbo et al. (2017) found a significant association between SCC and serum total protein and globulin concentration. Although the reason was not very clear, it can be partly explained by better immune status with greater globulin in the serum. In the present study, the serum concentration was not measured, however, the less SCC in cows supplemented with ADY illustrated that ADY may potentially increase the immune status and decrease inflammatory response. The quadratic decrease of SCC and MUN concentration in cows supplemented ADY in different doses suggested $20 \mathrm{~g} / \mathrm{d}$ per head should be the optimal dose for better nitrogen utilization and immune status.

Ruminal concentration of VFA is an important indicator to reflect feed degradation characteristics. Usually, greater VFA concentration is associated with greater OM digestibility. In the present study, the quadratic increase of ruminal VFA concentration was consistent with the quadratic increase of total-tract digestibility of OM. Both ruminal VFA concentration and $\mathrm{OM}$ digestibility peaked at ADY supplementation of $20 \mathrm{~g} / \mathrm{d}$ per head, which illustrated that this should be the optimal dose for OM digestibility.

Fiber is mainly degraded in the rumen and fermented to produce acetate. Previous studies demonstrated that ADY has benefits in improving cellulolytic bacteria activity, which resulted in greater fiber digestibility and greater acetate proportion (Fonty and Chaucheyras-
Durand, 2006). However, Vyas et al. (2014) and Jiang et al. (2017a) did not find an ADY effect on acetate production using a 3-wk experimental period. This differs from the linearly increasing acetate production with increasing ADY supplementation in the present study. Hasunuma et al. (2016) conducted a long-term experiment using ADY and monitored ruminal acetate for 15 wk. The increased ruminal acetate concentration in ADY-supplemented cows was observed until wk 15. Thus, the different results in acetate production between the present study and previous studies could be explained by the different durations of ADY supplementation. Moreover, according to (Chaucheyras-Durand et al., 2012), different ADY strains exhibit different effects on digestive microbiota. Thus, the different results of acetate production could be also due to the different ADY strains used in different studies.

An interesting finding in the present study is that NDF digestibility increased quadratically with increasing ADY supplementation. On the contrary, Ferraretto et al. (2012) conducted a study using 2 ADY doses and found that NDF digestibility improved by using a high ADY dose but not a low dose. Jiang et al. (2017a) also evaluated the dose effect using 2 different ADY doses. The researchers found that both low and high doses of ADY had a positive effect on NDF digestibility compared with control, but no difference was observed between these 2 doses. Ruminal microbiota of cows supplemented with a different dose of ADY was analyzed by Jiang et al. (2017b), who noted that the abundance of Butyrivibrio fibrisolvens, an important hemicellulolytic species, decreased in cows supplemented with a high dose of ADY. Although it is not clear why Butyrivibrio fibrisolvens decreased the high dose, the decreased cellulolytic bacteria abundance could partly explain the quadratic effect of ADY supplementation on NDF digestibility in dairy cows.

In the present study, the NDF digestibility ranged from 53.7 to $64.8 \%$, which was greater than the value (range of 45.0-54.5\%) reported by Jiang et al. (2017a). 
The forage used in the present diet consists of $25 \%$ corn silage, $15 \%$ alfalfa hay, and $2 \%$ oat hay (DM basis), whereas in Jiang et al. (2017a), the forage was $41.7 \%$ corn silage. As it is known that NDF in alfalfa hay is more digestible than corn silage (Eun and Beauchemin, 2007), the greater NDF digestibility in the present study should be expected. According to the meta-analysis published by Weld and Armentano (2017), NDF digestibility ranging from 28.8 to $66.8 \%$ were previously reported; therefore, the NDF digestibility value in the present study should be acceptable.

In the present study, although the blood concentration of total protein was not affected, BUN decreased with ADY supplementation. Together with greater CP digestibility and lower MUN concentration, nitrogen utilization might be improved in ADY-supplemented cows; thus, the greater milk protein yield in cows supplemented with ADY in the present should be explained. Similarly, Dehghan-Banadaky et al. (2013) also reported a decrease of BUN concentration in ADYsupplemented cows, illustrating that ADY may have some potential benefit in improving nitrogen utilization.

The concentration of blood glucose and NEFA are widely used to evaluate energy status in dairy cows. In the present study, lower NEFA concentration in ADYsupplemented cows illustrated that body fat mobilization might be decreased by ADY supplementation. Concentration of glucose is mainly affected by NFC digestibility. In the present study, glucose concentration increased quadratically with increasing ADY supplementation, which was consistent with the quadratically increased NFC digestibility. Greater glucose concentration in ADY-supplemented cows was also reported by Dehghan-Banadaky et al. (2013). In the present study, the lower NEFA and higher glucose concentration in ADY-supplemented cows demonstrated that ADY supplementation may improve the energy status by increasing NFC digestibility in dairy cows.

The $\mathrm{CH}_{4}$ production did not differ when expressed as grams per day, which was consistent with a previous study that found $\mathrm{CH}_{4}$ production was not affected by ADY supplementation (Bayat et al., 2015). As it is known that $\mathrm{CH}_{4}$ production is mainly modified by propionate fermentation in ruminants (Fukuzaki et al., 1990), the lack of ADY effect on $\mathrm{CH}_{4}$ production should be expected. In the present study, the $\mathrm{CH}_{4}$ production tended to decrease when expressed as grams per kilogram of FCM and digested NDF, although the tendency is quite weak. The ADY effect on $\mathrm{CH}_{4}$ production varies by different studies. Mwenya et al. (2004) reported a decrease in $\mathrm{CH}_{4}$ emissions by ADY supplementation. Bayat et al. (2015) found no effect of ADY on $\mathrm{CH}_{4}$ emissions, and Muñoz et al. (2017) even reported an increase in $\mathrm{CH}_{4}$ production when supplemented with ADY in lactating dairy cows. The different effects of ADY supplementation on $\mathrm{CH}_{4}$ production could be due to the different ADY strains, doses, or diets used by the different studies.

\section{CONCLUSIONS}

Supplementation of ADY in early-lactating cows at different doses had no influence on DMI and ruminal pH. Conversely, with certain doses, the milk yield and milk fat production increased by increasing nutrient digestibility. However, because bacteria populations in the digestive tract were not analyzed, the mechanism by which ADY affects nutrient digestibility is not clear and needs further exploration. Considering the relative greater milk yield, milk fat, and nutrient digestibility, and lower SCC and MUN concentration, $20 \mathrm{~g}$ of ADY per day per head should be the optimal supplementation dose in early-lactating dairy cows.

\section{ACKNOWLEDGMENTS}

This research was financially supported by the earmarked fund for Modern Agro-industry Technology Research System (CARS-36, Beijing, China), Hebei Dairy Cattle Innovation Team of Modern Agro-industry Technology Research System (HBCT2018120203, Shijiazhuang, China), key research and development project of Hebei (19226625D, Shijiazhuang, China), Precision Animal Husbandry Discipline Group Construction Project of Hebei Agricultural University (2020, Hebei, China), and Nation Natural Science Foundation of China (No. 31802254, Beijing, China). The authors thank the entire staff of Hongda Dairy Farm (Baoding, China) for their assistance in animal care and sample collection. The authors declare they have no actual or potential conflict of interest that could inappropriately influence in this work.

\section{REFERENCES}

AOAC International. 2005. Official Methods of Analysis. 18th ed. AOAC Int., Gaithersburg, MD.

Bayat, A. R., P. Kairenius, T. Stefański, H. Leskinen, S. ComtetMarre, E. Forano, F. Chaucheyras-Durand, and K. J. Shingfield. 2015. Effect of camelina oil or live yeasts (Saccharomyces cerevisi$a e$ ) on ruminal methane production, rumen fermentation, and milk fatty acid composition in lactating cows fed grass silage diets. J. Dairy Sci. 98:3166-3181. https://doi.org/10.3168/jds.2014-7976.

Bobbo, T., E. Fiore, M. Gianesella, M. Morgante, L. Gallo, P. Ruegg, G. Bittante, and A. Cecchinato. 2017. Variation in blood serum proteins and association with somatic cell count in dairy cattle from multi-breed herds. Animal 11:2309-2319. https://doi.org/10 $.1017 /$ S1751731117001227.

Chaucheyras-Durand, F., E. Chevaux, C. Martin, and E. Forano. 2012 Use of yeast probiotics in ruminants: Effects and mechanisms of action on rumen $\mathrm{pH}$, fibre degradation, and microbiota according 
to the diet. Pages 119-152 in Probiotic in Animals. E. Rigobelo, ed. InTech, Rijeka, Croatia.

Chaucheyras-Durand, F., and G. Fonty. 2002. Influence of a probiotic yeast (Saccharomyces cerevisiae CNCM I-1077) on microbial colonization and fermentations in the rumen of newborn lambs. Microb. Ecol. Health Dis. 14:30-36. https://doi.org/10.1080/ 089106002760002739.

Chaucheyras-Durand, F., S. Masséglia, and G. Fonty. 2005. Effect of the microbial feed additive Saccharomyces cerevisiae CNCM I-1077 on protein and peptide degrading activities of rumen bacteria grown in vitro. Curr. Microbiol. 50:96-101. https://doi.org/10 .1007/s00284-004-4433-1.

Chaucheyras-Durand, F., N. D. Walker, and A. Bach. 2008. Effects of active dry yeasts on the rumen microbial ecosystem: Past, present and future. Anim. Feed Sci. Technol. 145:5-26. https://doi.org/10 .1016/j.anifeedsci.2007.04.019.

Chung, Y. H., N. D. Walker, S. M. McGinn, and K. A. Beauchemin. 2011. Differing effects of 2 active dried yeast (Saccharomyces cerevisiae) strains on ruminal acidosis and methane production in nonlactating dairy cows. J. Dairy Sci. 94:2431-2439. https://doi .org/10.3168/jds.2010-3277.

Crossland, W. L., C. M. Cagle, J. E. Sawyer, T. R. Callaway, and L. O. Tedeschi. 2019. Evaluation of active dried yeast in the diets of feedlot steers. II. Effects on rumen $\mathrm{pH}$ and liver health of feedlot steers. J. Anim. Sci. 97:1347-1363. https://doi.org/10.1093/jas/ skz008.

de Ondarza, M. B., C. J. Sniffen, H. Graham, and P. Wilcock. 2010 Case study: Effect of supplemental live yeast on yield of milk and milk components in high-producing multiparous Holstein cows. Appl. Anim. Sci. 26:443-449. https://doi.org/10.15232/S1080 -7446(15)30626-4.

Degirmencioglu, T., S. Sentürklü, S. Özbilgin, and T. Özcan. 2013. Effects of S. cerevisiae addition to Anatolian water buffalo diets on dry matter intake, milk yield, milk composition and somatic cell count. Maced. J. Anim. Sci. 3:193-198.

Dehghan-Banadaky, M., M. Ebrahimi, R. Motameny, and S. R. Heidari. 2013. Effects of live yeast supplementation on mid-lactation dairy cows performances, milk composition, rumen digestion and plasma metabolites during hot season. J. Appl. Anim. Res. 41:137-142. https://doi.org/10.1080/09712119.2012.739085.

Desnoyers, M., S. Giger-Reverdin, G. Bertin, C. Duvaux-Ponter, and D. Sauvant. 2009. Meta-analysis of the influence of Saccharomyces cerevisiae supplementation on ruminal parameters and milk production of ruminants. J. Dairy Sci. 92:1620-1632. https://doi.org/ $10.3168 /$ jds.2008-1414.

DeVries, T. J., and E. Chevaux. 2014. Modification of the feeding behavior of dairy cows through live yeast supplementation. J. Dairy Sci. 97:6499-6510. https://doi.org/10.3168/jds.2014-8226.

Eun, J. S., and K. A. Beauchemin. 2007. Enhancing in vitro degradation of alfalfa hay and corn silage using feed enzymes. J. Dairy Sci. 90:2839-2851. https://doi.org/10.3168/jds.2006-820.

Ferraretto, L. F., R. D. Shaver, and S. J. Bertics. 2012. Effect of dietary supplementation with live-cell yeast at two dosages on lactation performance, ruminal fermentation, and total-tract nutrient digestibility in dairy cows. J. Dairy Sci. 95:4017-4028. https://doi .org/10.3168/jds.2011-5190.

Fonty, G., and F. Chaucheyras-Durand. 2006. Effects and modes of action of live yeasts in the rumen. Biologia 61:741-750. https://doi .org/10.2478/s11756-006-0151-4.

Fukuzaki, S., N. Nishio, M. Shobayashi, and S. Nagai. 1990. Inhibition of the fermentation of propionate to methane by hydrogen, acetate, and propionate. Appl. Environ. Microbiol. 56:719-723. https://doi.org/10.1128/AEM.56.3.719-723.1990.

Habeeb, A. A. M. 2017. Importance of yeast in ruminants feeding on production and reproduction. Ecol. Evol. Biol. 2:49-58. https:// doi.org/10.11648/j.eeb.20170204.11.

Hasunuma, T., Y. Uyeno, K. Akiyama, S. Hashimura, H. Yamamoto, H. Yokokawa, T. Yamaguchi, M. Itoh, H. Mizuguchi, S. Sato, M. Hirako, and S. Kushibiki. 2016. Consecutive reticular pH monitoring in dairy cows fed diets supplemented with active dry yeast during the transition and mid-lactation periods. Anim. Feed Sci.
Technol. 221:215-225. https://doi.org/10.1016/j.anifeedsci.2016 .09 .002 .

Jia, P., K. Cui, T. Ma, F. Wan, W. Wang, D. Yang, Y. Wang, B. Guo, L. Zhao, and Q. Diao. 2018. Influence of dietary supplementation with Bacillus licheniformis and Saccharomyces cerevisiae as alternatives to monensin on growth performance, antioxidant, immunity, ruminal fermentation and microbial diversity of fattening lambs. Sci. Rep. 8:16712. https://doi.org/10.1038/s41598-018 $-35081-4$.

Jiang, Y., I. M. Ogunade, K. G. Arriola, M. Qi, D. Vyas, C. R. Staples, and A. T. Adesogan. 2017a. Effects of the dose and viability of Saccharomyces cerevisiae. 2. Ruminal fermentation, performance of lactating dairy cows, and correlations between ruminal bacteria abundance and performance measures. J. Dairy Sci. 100:81028118. https://doi.org/10.3168/jds.2016-12371.

Jiang, Y., I. M. Ogunade, S. Qi, T. J. Hackmann, C. R. Staples, and A. T. Adesogan. 2017b. Effects of the dose and viability of Saccharomyces cerevisiae. 1. Diversity of ruminal microbes as analyzed by Illumina MiSeq sequencing and quantitative PCR. J. Dairy Sci. 100:325-342. https://doi.org/10.3168/jds.2016-11263.

Littell, R. C., P. R. Henry, and C. B. Ammerman. 1998. Statistical analysis of repeated measures data using SAS procedures. J. Anim. Sci. 76:1216-1231. https://doi.org/10.2527/1998.7641216x.

Lynch, H. A., and S. A. Martin. 2002. Effects of Saccharomyces cerevisiae culture and Saccharomyces cerevisiae live cells on in vitro mixed ruminal microorganism fermentation. J. Dairy Sci. 85:26032608. https://doi.org/10.3168/jds.S0022-0302(02)74345-2.

Malekkhahi, M., A. M. Tahmasbi, A. A. Naserian, M. Danesh-Mesgaran, J. L. Kleen, O. AlZahal, and M. H. Ghaffari. 2016. Effects of supplementation of active dried yeast and malate during sub-acute ruminal acidosis on rumen fermentation, microbial population, selected blood metabolites, and milk production in dairy cows. Anim. Feed Sci. Technol. 213:29-43. https://doi.org/10.1016/j anifeedsci.2015.12.018.

Mertens, D. R. 2002. Gravimetric determination of amylase-treated neutral detergent fiber in feeds with refluxing in beakers or crucibles: collaborative study. J. AOAC Int. 85:1217-1240.

Moallem, U., H. Lehrer, L. Livshitz, M. Zachut, and S. Yakoby. 2009. The effects of live yeast supplementation to dairy cows during the hot season on production, feed efficiency, and digestibility. J. Dairy Sci. 92:343-351. https://doi.org/10.3168/jds.2007-0839.

Muñoz, C., D. A. Wills, and T. Yan. 2017. Effects of dietary active dried yeast (Saccharomyces cerevisiae) supply at two levels of concentrate on energy and nitrogen utilisation and methane emissions of lactating dairy cows. Anim. Prod. Sci. 57:656-664. https://doi .org/10.1071/AN15356.

Mwenya, B., B. Santoso, C. Sar, Y. Gamo, T. Kobayashi, I. Arai, and J. Takahashi. 2004. Effects of including $\beta 1-4$ galacto-oligosaccharides, lactic acid bacteria or yeast culture on methanogenesis as well as energy and nitrogen metabolism in sheep. Anim. Feed Sci. Technol. 115:313-326. https://doi.org/10.1016/j.anifeedsci.2004 .03 .007 .

NRC. 2001. Nutrient Requirements of Dairy Cattle. 7th ed. Natl. Acad. Press, Washington, DC.

Phipps, R. H., J. I. D. Wilkinson, L. J. Jonker, M. Tarrant, A. K. Jones, and A. Hodge. 2000. Effect of monensin on milk production of Holstein-Friesian dairy cows. J. Dairy Sci. 83:2789-2794. https: //doi.org/10.3168/jds.S0022-0302(00)75176-9.

Pinloche, E., N. McEwan, J.-P. Marden, C. Bayourthe, E. Auclair, and C. J. Newbold. 2013. The effects of a probiotic yeast on the bacterial diversity and population structure in the rumen of cattle. PLoS One 8:e67824. https://doi.org/10.1371/journal.pone.0067824.

Popják, G., T. H. French, and S. J. Folley. 1951. Utilization of acetate for milk-fat synthesis in the lactating goat. Biochem. J. 48:411416. https://doi.org/10.1042/bj0480411.

Ran, T., Y. Z. Shen, A. M. Saleem, O. AlZahal, K. A. Beauchemin, and W. Z. Yang. 2018. Using ruminally protected and nonprotected active dried yeast as alternatives to antibiotics in finishing beef steers: growth performance, carcass traits, blood metabolites, and fecal Escherichia coli. J. Anim. Sci. 96:4385-4397. https://doi .org/10.1093/jas/sky272. 
Rice, E. M., K. M. Aragona, S. C. Moreland, and P. S. Erickson. 2019. Supplementation of sodium butyrate to postweaned heifer diets: Effects on growth performance, nutrient digestibility, and health. J. Dairy Sci. 102:3121-3130. https://doi.org/10.3168/jds .2018-15525.

Russell, J. B., and D. B. Wilson. 1996. Why are ruminal cellulolytic bacteria unable to digest cellulose at low pH? J. Dairy Sci. 79:1503-1509. https://doi.org/10.3168/jds.S0022-0302(96)76510 -4 .

Shen, J. S., Z. Chai, L. J. Song, J. X. Liu, and Y. M. Wu. 2012. Insertion depth of oral stomach tubes may affect the fermentation parameters of ruminal fluid collected in dairy cows. J. Dairy Sci. 95:5978-5984. https://doi.org/10.3168/jds.2012-5499.

Shen, Y., T. Davedow, T. Ran, A. M. Saleem, I. Yoon, C. Narvaez, T. A. McAllister, and W. Z. Yang. 2019a. Ruminally protected and unprotected Saccharomyces cerevisiae fermentation products as alternatives to antibiotics in finishing beef steers. J. Anim. Sci. 97:4323-4333. https://doi.org/10.1093/jas/skz270.

Shen, Y. Z., L. Y. Ding, L. M. Chen, J. H. Xu, R. Zhao, W. Z. Yang, H. R. Wang, and M. Z. Wang. 2019b. Feeding corn grain steeped in citric acid modulates rumen fermentation and inflammatory responses in dairy goats. Animal 13:301-308. https://doi.org/10 $.1017 /$ S1751731118001064.

Szucs, J. P., A. Suli, T. Halasz, A. Arany, and Z. Bodor. 2013. Effect of live yeast culture Saccharomyces cerevisiae on milk production and some blood parameters. Lucr. Stiint. Zooteh. Biotehnol. 46:40-44.

Van der Werf, J. H. J., L. J. Jonker, and J. K. Oldenbroek. 1998. Effect of monensin on milk production by Holstein and Jersey cows. J. Dairy Sci. 81:427-433. https://doi.org/10.3168/jds.S0022 $-0302(98) 75593-6$.
Van Keulen, J., and B. A. Young. 1977. Evaluation of acid-insoluble ash as a natural marker in ruminant digestibility studies. J. Anim. Sci. 44:282-287. https://doi.org/10.2527/jas1977.442282x.

Van Soest, P. J., J. B. Robertson, and B. A. Lewis. 1991. Methods for dietary fiber, neutral detergent fiber, and nonstarch polysaccharides in relation to animal nutrition. J. Dairy Sci. 74:3583-3597. https://doi.org/10.3168/jds.S0022-0302(91)78551-2.

Vyas, D., A. Uwizeye, R. Mohammed, W. Z. Yang, N. D. Walker, and K. A. Beauchemin. 2014. The effects of active dried and killed dried yeast on subacute ruminal acidosis, ruminal fermentation, and nutrient digestibility in beef heifers. J. Anim. Sci. 92:724-732. https://doi.org/10.2527/jas.2013-7072.

Weld, K. A., and L. E. Armentano. 2017. The effects of adding fat to diets of lactating dairy cows on total-tract neutral detergent fiber digestibility: A meta-analysis. J. Dairy Sci. 100:1766-1779. https:/ /doi.org/10.3168/jds.2016-11500.

\section{ORCIDS}

Yan Li ® https://orcid.org/0000-0003-3687-9048

Yizhao Shen (1) https://orcid.org/0000-0003-1678-7808

Mirielle Pauline @ https://orcid.org/0000-0001-8700-0035

Xiaojing Zhao @ https://orcid.org/0000-0002-6927-0338

Chongliang Bi ๑ https://orcid.org/0000-0002-9928-4378

Xiujiang Zhang @ https://orcid.org/0000-0001-8333-9058

Zhonghua Wang (i) https://orcid.org/0000-0001-7629-8227

Yanxia Gao (ㄴ) https://orcid.org/0000-0002-9436-693X

Jianguo Li 우 https://orcid.org/0000-0001-7090-1574 